Universities aND Colleges.

Universities and Colleges, Great Brilann: $£$ University of London

Victoria University of $\dddot{M}$ anchester

University of Birmingham ... ...

University of Wales $\ldots \quad \ldots \quad \ldots$

University of Liverpool

Leeds University

Bristol University $\quad \cdots \quad \cdots, \quad \cdots$

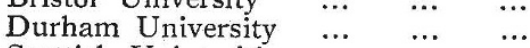

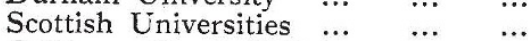

Colleges, Great Britain ...

University Colleges, Wales ...

Welsh University and Colleges : Additional grant.

Total for Universities and Colleges...

Intermediate Education, Wales.

Examination and inspection, grant in aid...

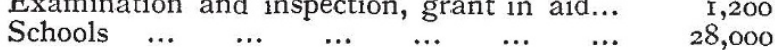

Total for Intermediate Education, Wales 29,200

$\begin{array}{lllr}\text { Grand total } & \ldots & \ldots & \frac{3^{21,700}}{500} \\ \text { Increase } & \ldots & \ldots & 50\end{array}$

Scotland.

Public Education.

Administration

Inspection

$\begin{array}{llll}\cdots & \ldots & \ldots & \ldots\end{array}$

Continuation classes and secondary school

Royal Scottish Museum, Edinburgh

Training of teachers...

Examination of accounts $\quad \ldots \quad \ldots$.

$$
\begin{aligned}
& \text { Total } \quad \ldots \quad \ldots \quad \ldots \quad 3,04 \mathrm{I}, 545 \\
& \text { Net decrease ... } \ldots . \quad 2,076
\end{aligned}
$$

Ireland.

Public Education.

Administration

$\begin{array}{llllll}\text { Training colleges } & \cdots & \cdots & \cdots & \ldots & 5^{\mathrm{I}, 7 \mathrm{I} 3}\end{array}$

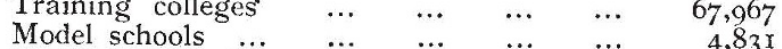

$\begin{array}{llllll}\text { National schools } & \ldots & \ldots & \ldots & \ldots & \text { I, } 963,830\end{array}$

Manual and practical instruction $\ldots . \quad \ldots .{ }_{13}, 767$

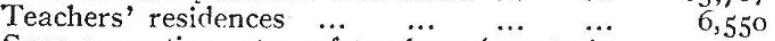

Superannuation, etc., of teachers (grants $\ldots$ aid)

Deduc:-

Gross total

60,593

$\frac{60,593}{2,203,804}$

Appropriations in aid ...

700

$$
\begin{array}{lllr}
\text { Net total } & \ldots & \ldots & \frac{2,203,104}{1,086}
\end{array}
$$

InTERMEDIATE Education.

Towards salaries of teachers, including cost of administration $\quad \ldots \quad \ldots . \quad \ldots$ Intermediate Education

Total NO. 2528 , VOL. IOI

90,000

\section{SCIENCE AND ART.}

Institutions of science and art $\quad \ldots \quad \ldots . \quad \ldots \quad \underset{48,6 \mathrm{I} 2}{\mathcal{C}_{2}}$

Schools of science and art, etc. $\quad \ldots \quad \ldots \quad$ II $4,0_{50}$

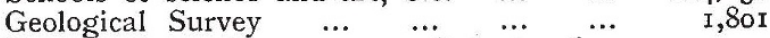

Examinations in courses of instruction conducted in technical schools $\ldots \quad \ldots \quad 700$

\section{Deduct-}

Gross total $\ldots \quad \ldots \overline{\mathrm{I}_{5}, \mathrm{I} 6_{3}}$

$\begin{array}{llllll}\text { Appropriations in } \text { aid } \ldots & \ldots & \ldots & \ldots & 1,770\end{array}$

Net total $\quad \ldots \quad \ldots \longdiv { x 6 _ { 3 } , 3 9 3 }$

Universities and Colleges.

Grants-

Queen's University of Belfast $\quad \ldots \quad \ldots \quad$ I8,000

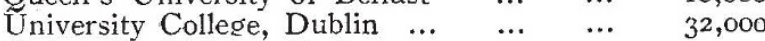

University College, Cork $\quad \ldots \quad \ldots \quad \ldots \quad \ldots \quad 20,000$

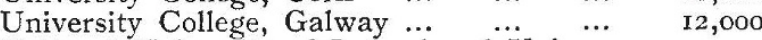

National University of Ireland and Univer-

sity College, Dublin $\quad \ldots \quad \ldots . \quad \ldots \quad r 2,350$

Additional grant to University College,

$\begin{array}{lllllll}\text { Galway } & \ldots & \ldots & \ldots & \ldots & \ldots & 2,000\end{array}$

Total $\quad \ldots \quad \ldots \quad \ldots \longdiv { 9 6 , 3 5 0 }$

Summary.

United Kingdom and England.

Board of Education

... $\quad \ldots \quad \ldots 19,206,705$

$\begin{array}{lllll}\cdots & \cdots & \cdots & \cdots & \text { I } 26, \mathrm{I}_{42}\end{array}$

$\begin{array}{llllll} & \ldots & \ldots & \ldots & \ldots & \text { I }, 639\end{array}$

$\begin{array}{lllll}\text { National Portrait Gallery } & \ldots & \ldots & \ldots & 3,779\end{array}$

$\begin{array}{llllll}\text { Wallace Collection } & \ldots & \ldots & \ldots & \ldots & 4,012\end{array}$

$\begin{array}{llllll}\text { London Museum } & \ldots & \ldots & \ldots & \ldots & 2,300\end{array}$

$\begin{array}{lllll}\text { Imperial War Museum } & \ldots & \ldots & \ldots & \text { I9,000 }\end{array}$

Scientific Investigation, etc. $\ldots \quad \ldots \quad \ldots \quad$ 54,24 I

Department of Scientific and Industria'

$\begin{array}{lllllll}\text { Research } & \ldots & \ldots & \ldots & \ldots & \ldots & \mathbf{1 4} 8,350\end{array}$

Universities and Colleges, Great $\dddot{\text { Britain, }}$

and Intermediate Education, Wales $\quad \ldots \quad 321,700$

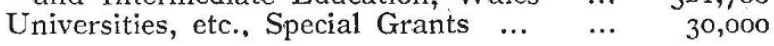

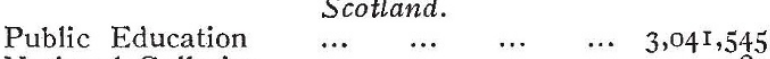

$\begin{array}{lllllr}\text { National Galleries } & \ldots & \ldots & \ldots & \ldots & 3,041,545 \\ & & \ldots & \ldots & \ldots & 4,283\end{array}$

Ireland.

$\begin{array}{llllll}\text { Public Education } & \ldots & \ldots & \ldots & \ldots & 2,203,104\end{array}$

Intermediate Education (Ireland) $\quad \ldots \quad \ldots \quad \ldots \quad 90,000$

Endowed Schools Commissioners $\ldots . \quad \ldots \quad r \quad 855$

$\begin{array}{llllll}\text { National Gallery } & \ldots & \ldots & \ldots & \ldots & \text { I, } 830\end{array}$

$\begin{array}{llllll}\text { Science and Art } & \ldots & \ldots & \ldots & \ldots & 163,393\end{array}$

$\begin{array}{llllr}\text { Universities and Colleges } & \ldots & \ldots & \ldots & 16,393 \\ \end{array}$

Total $\quad \ldots \quad \ldots \quad \ldots 25,529,228$

Net decrease ... ... 690,803

\section{UNIVERSITY AND EDUCATIONAL} INTELLIGENCE.

IT is stated in Science that the Carnegie Corporation has presented McGill University with 200,00ol. in recognition of the University's "devoted service and sacrifice towards Canada's part in the war."

THE sum of $4000 l$. has been given by Mr. F. W. Chance to the Carlisle Education Committee for the establishment of a laboratory and lecture-room for chemistry and physics. An income of $600 l$. a year is assured for five years. The gift is intended as a memorial to the late Capt. A. F. Chance.

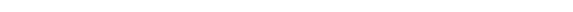


Mr. George Matthai, of Emmanuel College, Cambridge, who for three years held the Mackinnon studentship (on the biological side) of the Royal Society, has been appointed by the Secretary of State for India to the Indian Educational Service as professor of zoology, Lahore, Punjab, India.

The Markham Skerritt memorial prize of the University of Bristor is awarded to the medical member of the University of Bristol who has in the previous three years published the best original work in any branch of medical science. The consideration of this year's award will be given by the medical board of the University on May 3 .

Notice is given of the impending award of the Lindley studentship in physiology of the University of London. The studentship is of the value of rool., and awarded every third year. Statements of the qualifications of intending candidates and particulars of their proposed modes of research must reach the academic registrar of the University by April 30. Applications for grants from the Dixon fund must be received not later than the first post on May I5. $_{5}$.

Among the lectures arranged at University College, Gower Street, W.C.I, for the third term of the current session, and announced in the London University Gazette, are the following: $1 \mathrm{~A}$ course on "Some Biological Problems of To-day" includes lectures beginning at 5 p.m. : on May ${ }_{13}$, by Dr. H. M. Vernon, on industrial efficiency and fatigue; on May 27 , by Prof F. W. Oliver, on substitution of raw materials; on June 3 , by Dr. R. C. McLean, on the anaerobic treatment of wounds; and on June ro, by Prof. H. R. Kenwood, on fresh air and efficiency. On May 2, at 2.30 p.m., Prof. W. M. Flinders Petrie gives the first lecture of a course on the "Objects of Daily Life." The lectures are open to the public without fee.

The new South African University of Cape Town was inaugurated on April 2. The Prince of Wales has accepted the Chancellorship, and sent an appropriate message wishing success to the new venture. As has been recorded in these columns already, three Acts were passed by the Union of South Africa in I9I6 constituting and establishing three universities in the Union. The University of the Cape of Good Hope, together with certain institutions, was by one of these Acts incorporated in a federal University; a second Act provides that the Victoria College, Stellenbosch, in the Cape of Good Hope, shall be incorporated as a University; and a third Act similarly incorporates South African College, Cape Town, as a University. As a result of these Acts, the University of the Cape of Good Hope becomes the University of South Africa, with its administrative seat at Pretoria, and it has six constituent colleges. The Victoria College, Stellenbosch, becomes the University of Stellenbosch, with its seat in the division of Stellenbosch, in the province of the Cape of Good Hope. The South African College becomes the University of Cape Town, and its seat is to be upon the Groote Schuur estate in the Cape Division of the Capé of Good Hope. The Times correspondent at Cape Town states that at the inauguration of this University stimulating speeches were delivered by Lord Buxton, in his double capacity of Governor-General of the Union and visitor of the new University, Mr. Malan, Minister of Education, and the Principal, Prof. J. C. Beattie.

Prof. R. Wallace, of the Department of Agriculture in the University of Edinburgh, has addressed a long open letter to the Prime Minister "urging postponement until after the war, as well as the effective recasting, of the English and Scottish Education Bills -legislation dangerous to the stability of the Empire and subversive of the soundest canons of education." It would have been a more gracious act had Prof. Wallace addressed himself to the respective heads of the Departments for Education of England and Scotland, and especially to Mr. Fisher, who has shown his complete familiarity with questions of education, and has been at such pains to make clear the principles upon which all sound education should be based and the means whereby they are to be realised. It would be well for Prof. Wallace to turn his attention to the preface written by $\mathrm{Mr}$. Fisher by way of introduction to his educational reform speeches, wherein he says that "many people have a very limited faith in the value of education. They are prepared to believe that it is good for well-to-do people-for the aristocracy of the human race, upon whom the task of intellectual leadership is devolved. . . . They remember their own schooldays, and... reflect that schooling did not help them, so far as they can remember, to earn a single shilling, and so they think and talk against education, and, if they are very silly, write books against it." Prof. Wallace, with all his profession of intimate knowledge of the 85 per cent. of the population and its real needs, cannot ignore the unanimous resolve of the great body of the elementary-school teachers to give the fullest support to the Education Bill, since they are in the main drawn from the same class as their pupils, and must have actual experience of their needs. They are convinced that the true policy is "to put the whole child to school," and its solution is not to be found " in relays of children [who] should follow each other during the working hours of the day to maintain a continuous supply of labour," nor, if the child "is to be a competent attendant on either cattle or sheep," he "must grow up with them and begin to know and understand them before he is ten," as Prof. Wallace demands.

\section{SOCIETIES AND ACADEMIES. LONDON.}

Geological Society, March 20.-Mr. G. IV. Lamplugh, president, in the chair.-Dr. W. F. Smeeth: The geology of Southern India, with particular reference to the Archæan rocks of the Mysore State. The geological formations of Southern India consist largely of a highly folded and foliated complex of Archæan gneisses and schists, followed by patches of pre-Cambrian slates, limestones, and quartzites; with these are associated basic lava-flows and ferruginous jaspers. The remaining formations consist of remnants of the Gondwana Beds (Coal Measures of Permo-Carboniferous age), a few patches of Cretaceous rocks, some Tertiary and Pleistocene deposits, and recent sands and alluvium, all situated along the coastal margins of the Peninsula. The scanty post-Archæan record of Southern India was contrasted with the formations of Northern India which record oft-repeated movements culminating in the rise of the Himalaya in Tertiary times and accompanied by igneous activity on a gigantic scale. The history of the various views which have been held concerning the Archæan complex were reviewed. In $19 \mathrm{I}_{3}$ Holland produced a classification of the pre-Cambrian rocks of India which exhibits a remarkable parallelism with that given by Lawson (I9I3) for the pre-Cambrian of Canada. The work of the Mysore Geological Survey eliminated the fundamental gneissic complex, and showed that within the area of the Mysore State the oldest rocks were the Dhárwár system, which had been intruded into by at least four successive granitegneisses. The Mysore Archæan succession is either incomplete, or does not fit in with the classifications of Holland and Lawson. Holland's classification dealt

$$
\text { NO. } 2528 \text {, VOL. IOI] }
$$

